\title{
LETTER
}

\section{RAD51C germline mutations in breast and ovarian cancer patients}

\author{
Mohammad R Akbari', Patricia Tonin 2,3 , William D Foulkes ${ }^{2,3,4}$, Parviz Ghadirian ${ }^{5}$, Marc Tischkowitz ${ }^{2,4}$ and Steven A Narod*1
}

The two breast cancer genes $B R C A 1$ and $B R C A 2$ account for approximately one-half of cases of hereditary breast cancer, and other genes, such as BRIP1, PALB2, and P53, account for a small additional fraction [1]. Recently, it has been proposed that $R A D 51 C$ is also a breast cancer susceptibility gene [2]. A bi-allelic mutation of RAD51C was originally found in a family from Pakistan with features of Fanconi anemia [3]. Because several genes in the Fanconi anemia gene family are also breast cancer susceptibility genes (including BRCA2 (FANCD1) [4], BRIP1 (FANCJ) [5] and PALB2 (FANCN) [6]), Meindl and colleagues hypothesised that $R A D 51 C$ might be a breast cancer gene [2]. A germline mutation was seen in 6 of 480 (1.3\%) breast/ovarian cancer families from Germany, which had previously been found to be negative for mutations in BRCA1 and BRCA2. In each of the six families, the putative mutation co-segregated with the relevant cancers [2]. Each family with a mutation contained at least one case each of breast and ovarian cancer.

In order to confirm these findings, we sequenced the nine coding exons of RAD51C in the germline DNA of 454 patients with familial breast/ovarian cancer. The mean age at diagnosis of the breast cancers was 44.7 years (range 21 to 65) and the mean age of diagnosis of the ovarian cancers was 47.9 years (range 23 to 60 years). All patients were previously found to be negative for $B R C A 1$ and BRCA 2 mutations. Each proband had at least two affected first- or second-degree relatives. Eighty-five percent of the families contained at least one case of ovarian cancer. One-hundred patients were Jewish, 152 were French-Canadian and 202 were of various other ethnic origins. All subjects provided written informed consent to participate in the study. The study protocol was approved by the ethics committee of the Women's College Research Institute, protocol number 2007-0036-B.

\footnotetext{
*Correspondence: Steven.narod@wchospital.ca

'Women's College Research Institute, University of Toronto, Toronto, Ontario M5G 1N8, Canada

Full list of author information is available at the end of the article
}

We found no deleterious $R A D 51 C$ mutation among the 454 patients. We found a novel c.146-8A $>\mathrm{G}$ splicing variant in three of 100 Jewish breast cancer patients, but this variant was also present in 12 of 190 Jewish controls. In addition, we found one polymorphic missense variant (p.126Ala $>$ Thr or rs61758784) in three patients and one (p.287Thr>Ala or rs28363317) in four patients. Based on the prevalence of mutations in the initial report [2], we expected to identify approximately five families with a deleterious germline $R A D 51 C$ mutation. It is of interest that the mutations in the German families were all different, and therefore the discrepant results cannot be explained by the presence of $R A D 51 C$ founder alleles in Germany. Perhaps RAD51C mutations are not as common as the initial report suggests.

\section{Competing interests}

The authors declare that they have no competing interests.

\section{Author details}

'Women's College Research Institute, University of Toronto, Toronto, Ontario M5G 1N8, Canada. ${ }^{2}$ Program in Cancer Genetics, Departments of Human Genetics, Medicine and Oncology, McGill University, Montreal, Quebec H2W 1S6, Canada. 3The Research Institute, McGill University Health Centre, Montreal, Quebec H3G 1A4, Canada. ${ }^{4}$ Segal Cancer Centre, Lady Davis Institute, Jewish General Hospital, Montreal, Quebec H3T 1E2, Canada. ${ }^{5}$ Epidemiology Research Unit Research Centre, CHUM- Hôtel-Dieu, University of Montreal, Montreal, Quebec H2W 1T7, Canada.

Published: 19 August 2010

\section{References}

1. Walsh T, King MC: Ten genes for inherited breast cancer. Cancer Cell 2007, 11:103-105.

2. Meindl A, Hellebrand H, Wiek C, Erven V, Wappenschmidt B, Niederacher D, Freund M, Lichtner P, Hartmann L, Schaal H, Ramser J, Honisch E, Kubisch C, Wichmann HE, Kast K, Deissler H, Engel C, Müller-Myhsok B, Neveling K, Kiechle M, Mathew CG, Schindler D, Schmutzler RK, Hanenberg H: Germline mutations in breast and ovarian cancer pedigrees establish RAD51C as a human cancer susceptibility gene. Nat Genet 2010, 42:410-414.

3. Vaz F, Hanenberg H, Schuster B, Barker K, Wiek C, Erven V, Neveling K, Endt D, Kesterton I, Autore F, Fraternali F, Freund M, Hartmann L, Grimwade D, Roberts RG, Schaal H, Mohammed S, Rahman N, Schindler D, Mathew CG: Mutation of the RAD51C gene in a Fanconi anemia-like disorder. Nat Genet 2010, 42:406-409.

4. Wooster R, Bignell G, Lancaster J, Swift S, Seal S, Mangion J, Collins N, Gregory S, Gumbs C, Micklem G: Identification of the breast cancer susceptibility gene BRCA2. Nature 1995, 378:789-792.

5. Seal S, Thompson D, Renwick A, Elliott A, Kelly P, Barfoot R, Chagtai T, Jayatilake H, Ahmed M, Spanova K, North B, McGuffog L, Evans DG, Eccles D; Breast Cancer Susceptibility Collaboration (UK), Easton DF, Stratton MR, Rahman N: Truncating mutations in the Fanconi anemia J gene BRIP1 are 
low-penetrance breast cancer susceptibility alleles. Nat Genet 2006, 38:1239-1241

6. Rahman N, Seal S, Thompson D, Kelly P, Renwick A, Elliott A, Reid S, Spanova K, Barfoot R, Chagtai T, Jayatilake H, McGuffog L, Hanks S, Evans DG, Eccles D; Breast Cancer Susceptibility Collaboration (UK), Easton DF, Stratton MR: PALB2, which encodes a BRCA2-interacting protein, is a breast cancer susceptibility gene. Nat Genet 2007, 39:165-167.

\section{doi:10.1186/bcr2619}

Cite this article as: Akbari MR, et al:: RAD51C germline mutations in breast and ovarian cancer patients. Breast Cancer Research 2010, 12:404. 